\title{
Towards Substantive Democracy In Indonesia: A Viewpoint
}

\author{
I Made Gede Ray Misno \\ Department of Public Administration, STISPOL Wira Bhakti, Denpasar, Bali \\ Email: raymisno@yaoo.co.id
}

\begin{abstract}
Democracy is the most appropriate choice for our nation in carrying out the life of the nation and state. With democracy, the political rights of every citizen are guaranteed to be the same. Every citizen has the right to vote and be elected into political power, in contrast to monarchies where hereditary law applies. Because all citizens have the same rights and obligations in politics, democracy can only work effectively if these political positions are filled or held by people who have good qualifications, competences, and morals, so that they are able to represent people. who have given him the confidence to occupy a given political position with the aim of mutual welfare, as stated in the Preamble to the 1945 Constitution.
\end{abstract}

Keywords: Democracy, nation-state, politic, constitution

\section{INTRODUCTION}

Since the era of the independence struggle, the Indonesian nation has committed itself to democracy as an alternative to the form of life and authoritarianism. At the beginning of the independence revolution, that determination was embodied in the constitution as the blueprint for an independent Indonesian State. Even in the alternative constitution that was adopted at the middle and end of the revolution, this commitment to democracy is maintained. Likewise, in the constitution that the Constituent Assembly failed to enact as the result of the 1955 election. Even in the amended constitution in this reform era, democracy was formulated in more detail (Arbi Sanit, 2005).

However, after the Indonesian nation was independent for more than six decades, most Indonesians were not aware of and lived democracy comprehensively and synchronously. Even among the elite and the middle class of society, there are still discourses on the principles of ideology and praxis of democratic power. So, it is not surprising that the practice of democracy in various aspects of life is colored by symptoms of controversy, inconsistency, and incompleteness, which together present the problem of the rationality of Indonesian democracy.

Although a few years ago there was greater room for freedom of opinion, assembly and association which was followed by the opening of freedom of the press, 
release of political prisoners and democratic elections, some of these freedoms are necessary conditions - not sufficient conditions - for the promotion and promotion of and comprehensive protection of human rights. There is no guarantee that this freedom is fully protected and that state authoritarianism will not return (Hendardi, 2005).

Since the reformation was rolled out, we have held elections 4 times. However, the independent elections held by the General Election Commission (KPU) -according to the 1945 Constitution, article $22 \mathrm{E}$ paragraph 5- have only 3 times nationally, namely the 2004 Election, the 2009 Election, and 2014. The demands of the people who hope that elections are held more openly and democratically with the hope of bringing prosperity (substantive democracy) have not yet been realized. So that raises doubts that democracy is not the right system to be implemented in Indonesia, democracy can only be applied in countries that have achieved prosperity. There is a contradiction, even though we are democracy as a means to achieve prosperity. The question is whether democracy, which has been the choice of the state system since the revolution to date, cannot bring prosperity.

\section{LIERATURE REVIEW}

\section{Our Democratic Position}

Democracy as a state administration system must be supported by a strong and modern political party. Because democracy is a system of government from the people, by the people, to the people, which is represented by political parties as its pillars. However, until now, political parties in Indonesia have only become administrative, political parties. This is evident from the requirements of political parties to become election participants only to fulfill administrative requirements, as stipulated in Article 8 paragraph 2 of Law No. 8 of 2012 concerning the Election for Members of DPR, DPD and DPRD which reads, among other things, to become a participant in the Election of a Political Party must have management in all provinces, have a membership of at least 1000 or 1/1000 (one thousandth) of the total population in the management of a political party district / city level, has a secretariat, and so on.

Zoemrotin K. Susilo and Papang Dayat in the book Kratos Minus Demos "Indonesian Democracy, Notes from Below", quoted Charles Tilly who classified democracy into four dimensions commonly used by research experts, first, the constitutional dimension, where a democratic system is defined by its completeness the legal framework for guaranteeing the infrastructure of democracy, especially certain political policies. Second, the procedural dimension, emphasizes narrow state practices related to the validity of a democratic process. This approach focuses on a fair and fair election process. Third, the substantive dimension, where the democratic process is conditioned as a means of achieving the substantive goals of society, such as social welfare, justice, security and peace. Fourth, the process-oriented dimension, 
which emphasizes the quality of effective public participation, equal opportunities from all elements of society, public access and control in making strategic policies.

Of the four dimensions of these categories, it turns out that the political parties participating in the election have only reached the constitutional dimension stage because they are only able to complement the formal legal framework for democratic infrastructure. In fact, the Indonesian people have high expectations from the General Election, so that a stable government (read: legislative and executive) can bring prosperity. Meanwhile, political parties as representatives of the people in government are still engrossed in the constitutional dimension. This is why people do not believe that democracy implemented in the form of elections will bring prosperity.

However, as a process of maturing democracy, elections must be held continuously, and consciously political parties must be willing to correct their weaknesses. Democracy is simply a system applied to seize (share) power by the people, which is presented by political parties. Thus, political parties as pillars of democracy must be strong and modern, in order to achieve the substantive dimension of democracy category and then to a process-oriented dimension, as explained above.

For this reason, political parties must carry out party functions, and this should be stipulated in the Election Law. There must be an article stipulating that political parties are obliged to carry out sustainable political recruitment within a period of 5 (five) years and be reported to the relevant agencies. After that, a political party is obliged to provide political education to its cadres as an obligatory condition for seizing political office according to its level. For example, legislative and executive candidates nominated by political parties must have qualifications and competency certifications appropriate to their level and authority.

Unlike today, one of the requirements for legislative candidates who are not balanced with their competence is to only be able to speak, read and write in Indonesian (article 51 paragraph 1, letter d, Law No. 8 of 2012 on Legislative Elections). In fact, the legislature has extraordinary powers, namely, legislation, budgeting, and controlling. Meanwhile, the executive (regional head) executes the budget prepared and approved by the legislator to organize governance and development.

Political parties only pursue pragmatic victories to gain power. But after coming to power, they don't understand what to do with that power. Legislative power that should be exercised by making laws or regional regulations (Perda) that protect the people actually torments the people and does not take sides in the interests of the people. Power to create budgets (budgeting), only for personal or group gain, and having affairs with executives while performing supervisory duties (controlling).

\section{Increase the Qualifications and Competence of Candidates}

As long as the political parties did not carry out their party functions properly and measured, democracy will never produce welfare for the people (substantive 
democracy). With any democratic system or Election system - whether a closed proportional system or a pure open proportional system as currently applied, as long as political parties consider the Election to be only a 5 (five) yearly celebration, political recruitment is only carried out ahead of the Election, and the people are only considered a commodity, then these are not positive democratic patterns.

In the future, electoral laws need to be considered and drafted, which require qualifications and competences for eligible participants. If teachers must have the competence to teach, tourism actors must have competence, security guards must also have competence, and other professions must have competence, then state administrators with extraordinary authority such as legislators should also have qualifications and competences according to their level.

Article 51 of Law No. 8 of 2012 concerning the General Election for the DPR, DPD, DPRD, must be revised. The requirements to be loyal to Pancasila, UUD 1945, and loyal to the Republic of Indonesia are not enough just a statement letter. There should be a Lemhanas certification established from the National to Regency / City levels. Even the worst, as stated above, is the requirement for legislative candidates to be proficient, read and write in Indonesian.

There should be a school for candidate leaders for legislative candidates prepared by political parties within 5 (five) years before the election, from the national level to the district/city level as well. The Ministry of Home Affairs, as a political party supervisor, collaborates with the National Defense Institute and the Institute of Domestic Governmental Sciences (IIPDN) to prepare a curriculum for its equivalence, so that the certification is clear and measurable. For example, candidates for DPRD districts/cities must have certification equivalent to the position of Head of Division (Kabag), for candidates for Provincial DPRD must have certification equivalent to Head of Bureau (Karo) or Head of Agency (Kaban), and candidates for DPR RI must have certification equivalent to Director. General (Director General). Because it is at these levels that they work and coordinate. Meanwhile, matters of doctrine and propaganda are matters of political parties.

Recently, the requirements for political parties participating in the General Election do not need administrative requirements, as stated in article 8 of Law no. 8 Th. 2012, that is, has secretarial, support, and so on. However, the political parties participating in the General Election must have candidates who have the qualifications and competencies according to their level, as mentioned above. Political parties must carry out party functions, where they must carry out sustainable political recruitment, provide political education both formal and informal, then seize political positions with cadres whose qualifications and competences have been prepared. In this way, a modern and strong party with a healthy democracy will be formed. So, the people will surely welcome the election with joy and no longer apathetic. 


\section{Election Organizer Integrity}

On the other hand, the General Election Commission (KPU) as the national election organizer must have independence and integrity. The independence of KPU commissioners is absolutely necessary to ensure the quality of the election. KPU commissioners must not take sides with election participants and must not be influenced by political pressures. KPU commissioners must be guided by the constitution, both laws and regulations that are under it, in deciding policy.

In terms of integrity, the commissioner must meet the dimensions of integrity, among others, First; Perfection, a perfect human being is a human who has a normal physique, is intellectually intelligent, and morally has a good personality. Because the implementation of the Election involves so many people, such a large budget, and a very heavy workload, and is monitored from various points of view, KPU commissioners must have good physical strength, intelligence, and morality.

Second; Unity, meaning not divided, inseparable, and not divided. The unity, in this case, is the ability of election administrators to cooperate without being separated. This means that parts of the work may be different but in the same corridor. As far as possible, differences of opinion are facilitated, but always in a forum for the unification of opinions so that all activities are carried out properly. Election administrators must have a spirit of unity and integrity in conducting the Election. There is no individual KPU superman, but the KPU is superteam

Third; Integrity is a sign of organized activity. KPU commissioners must have a spirit of integrity, meaning that in carrying out their duties, they are able to combine all their potentials to carry out their duties as well as possible. This integration has mental-spiritual readiness and good intelligence. Due to such a large task load, with such great temptations, KPU commissioners must be able to integrate all their potential so that the implementation of the Election can run according to predetermined principles and adhere to the principles of Election administration.

Fourth; Sincerity is to carry out tasks as well as possible with high ideals. Have the will to hold an honest and fair election. Carry out tasks seriously with the concept of yadnya, carry out work without being tied to the results of the work (Bhagawad Gita sloka 3.19). Sincerity and sincerity in carrying out work make you feel comfortable in doing your job.

Fifth; Honesty, KPU commissioners must be honest with themselves, which is the beginning of being honest with others. This honesty can only be seen from openness. Organizing an open election is an effort to increase the honesty of election administrators. An election that is held honestly will be able to produce quality democracy.

Sixth; Anti-bribery, KPU commissioners must avoid bribery efforts carried out in various ways. The most common is that bribes ask for decisions according to their wishes, while those who are bribed get rewards for decisions they make. Therefore, KPU commissioners must have anti-bribery integrity so that they are protected from 
collusion, corruption and nepotism $(\mathrm{KKN})$. Thus of course it will be able to produce decisions that are beneficial to all Indonesian people.

\section{CONCLUSION}

Democracy is the most appropriate choice for the Indonesian nation in the administration of the State, because only with a democratic system all people have the same rights to be able to sit in government. Only this democracy needs to be understood together that democracy is not the goal of the State, but a tool to achieve the goals of the State according to the 1945 Constitution, namely to achieve prosperity (substantive democracy). In order to achieve substantive democracy, political parties must be filled with people who have qualifications and competence as well as morals. For this reason, political parties must carry out their party functions in a sustainable, consistent and measurable manner. Political parties must conduct regular political recruitment, provide political education, then take over political positions, so as to form strong and modern political parties. On the other hand, the KPU as the national election organizer, must have independence and integrity. KPU must adhere to the principles of organizing elections, namely; independence, impartiality, integrity, transparency, efficiency, professionalism.

\section{REFERENCES}

Haris Syamsuddin, 2014. Partai, Pemilu, dan Parlemen Era Reformasi, Jakarta: Yayasan Pustaka Obor Indonesia

Marijan Kacung Prof. DR, 2010. Sistem Politik Indonesia, "Konsolidasi Demokrasi Pasca Orde Baru", Jakarta: Kencana Prenada Media Group

Mujani Saiful, Liddle William R, Ambardi Kuskridho, 2012. Kuasa Rakyat “Analisis tentang Perilaku Memilih dalam Pemilihan Legislatif dan Presiden Pasca Orde Baru", Jakarta: Mizan Publika

Pamungkas Sigit, 2012. Partai Politik “Teori dan Praktik di Indonesia”, Jogjakarta: Institute for Democracy and Welfarism

Priyono Herry B. Et-al, 2012. Kratos Minus Demos “Demokrasi Indonesia, Catatan dari Bawah", Jakarta: Yayasan Pustaka Obor Indonesia

Ramlan S, Supriyanto Didik, Topo S., 2008. Perekayasaan Sistem Pemilu "Untuk Pembangunan Tata Politik Demokratis", Bandung: Kemitraan

Revitch Diane \& Thernstrom Abigail, 2005. Demokrasi Klasik \& Modern, Jakarta: Yayasan Pustaka Obor Indonesia

Sanit Arbi Drs., Hendardi, 2005. Menggugat Negara: Rasionalitas demokrasi, HAM dan Kebebasan, Jakarta: PBHI 